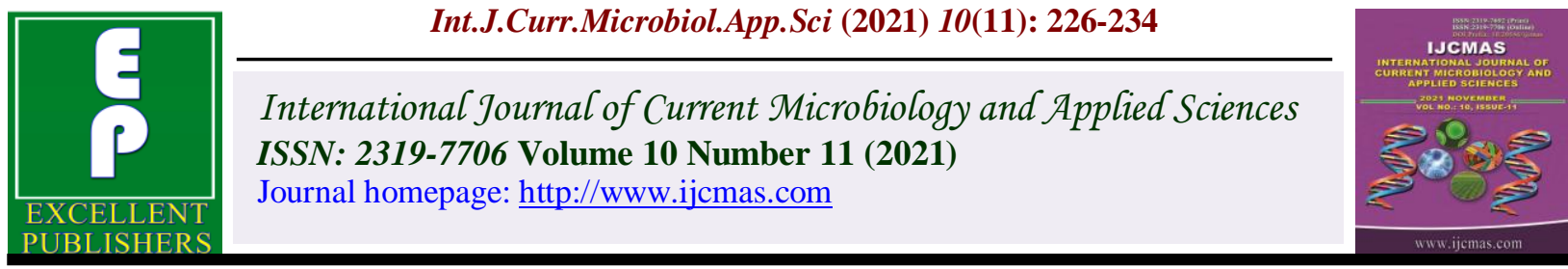

\title{
Microbiological Quality of Food and Ready Meals Sold in Fast Food Restaurants on the Campus of NANGUI ABROGOUA University in Abidjan (Ivory coast)
}

\author{
YAO Kouadio ${ }^{*}$, DAN Chépo Ghislaine ${ }^{1}$, NANGA Yessé Zinzendorf ${ }^{2}$, \\ KOMADE Thierry ${ }^{1}$, LOUKOU Yao Guillaume ${ }^{2}$ and KOUAME Lucien Patrice ${ }^{1}$
}

${ }^{1}$ Department of Food Science and Technology, University of Nangui Abrogoua, Laboratory of Biocatalysis and Bioprocessing, 02 BP 801 Abidjan 02, Côte d'Tvoire

${ }^{2}$ Department of Microbiology, National Laboratory of Public Health, 18 BP 2403 Abidjan 18, Côte d'Ivoire

*Corresponding author

\section{Keywords}

Microbiological quality, Ready meals, Campus, NANGUI ABROGOUA, Abidjan

Article Info

Received: 06 October 2021 Accepted: 05 November 2021 Available Online: 10 November 2021
The objective of this study was to analyze the microbilogical quality of foods sold in fast food restaurants on the campus of NAGUI ABROGOUA University (UNA). The detection and enumeration of total mesophilic aerobic bacteria, total and fecal coliforms, Salmonella, Staphylococcus aureus, sulfite-reducing anaerobes (ASR) and Clostridium perfringens were carried out according to the standard methods in force. In 3 months, 36 samples of ready meals from 7 sites were collected and analyzed. The results obtained revealed that the germ loads (colony forming unit : CFU) vary according to the nature of the germ, its origin and the nature of the food sampled. The charges in GAM vary from $9.4108 \pm$ to $1.5108 \mathrm{CFU} / \mathrm{g}$ to $6.3101 \pm 4.5101 \mathrm{CFU} / \mathrm{g}$. Overall, attiéké-garba and its condiments contain most of the germs sought with the exception of Salmonella which are absent in all the dishes analyzed. Thus, in terms of microbiological quality, $60 \%, 33.3 \%, 25 \%$ and $13.3 \%$ of the samples taken respectively from the school office aera, IREN - market and fixed restaurant sites are of non-microbiological quality satisfying the standards. This non-compliance is more attributable to attiéké-garba and its condiments contaminated with coliform strains, in particular Escherichia coli and strains of Staphylococcus aureus. It is therefore necessary to improve the hygienic quality of meals served in fast food restaurants on the campus of NANGUI ABROGOUA University (UNA), in particular attiéké-garba condiments and curdled milk to ensure better consumer safety.

\section{Introduction}

Collective catering is a real major need in modern societies due to its nutritional and socioeconomic importance. In Africa, rapid collective food, mass or street food is a very widespread phenomenon and participates daily in the eating habits of millions of people in 
large cities of developing countries (Ohiokpehai, 2003; Neffati et al., 2004). The term "rapid collective street or mass food" designates foods and beverages ready to be consumed, prepared or sold by street vendors or on fixed fast food restaurants on the outskirts of streets and in similar public places (FAO, 2007).

This type of rapid collective feeding, highly developed in Côte d'Ivoire as elsewhere, also affects most African university campuses (Chauliac et al., 1998; FAO, 2007). On the campus of NANGUI ABROGOUA University in the city of Abidjan (economic capital of Côte d'Ivoire), collective fast food or street food sold seems to occupy a prominent place because of the craze that they arouse many players in the university space. This undoubtedly contributes to the well-being and comfort of the students who spend all day and night on campus. The foods and menus offered are often traditional foods made from local products and new dishes adapted to the low incomes of many residents and university actors (Drabo et al., 2009; Ahota et al., 2010).

However, these new menus can sometimes be a source of many problems, including food poisoning. According to a WHO report (2009), outbreaks of serious food-borne infectious diseases have occurred in recent years in several African countries, in connection with the flourishing of quickservice restaurants. Collective foodborne illnesses (TIAC) are frequent in Africa and remain a major public health problem despite the progress made in their prevention (Barro et al., 2002; WHO, 2009; Ahota et al., 2010). These infections affect about $30 \%$ of individuals each year around the world and nearly $80 \%$ of reported epidemics originate from fast food restaurants (Chapman et al., 2010; Ahota et al., 2010). In Côte d'Ivoire, TIACs are not uncommon, according to Barro et al., (2002) and Chauliac et al., (1998).
According to these authors, their frequency is largely underestimated by the health authorities. Their origins are rarely elucidated due to the weakness of diagnostic means, especially microbiological means (Fayomi et al., 1992).

This study aims to analyze the microbiological quality of foods sold in fast food restaurants on the university campus of NANGUI ABROGOUA University (UNA).

\section{Materials and Methods}

\section{Nature and period of study}

This is a three-month prospective study; for the period from December 15, 2020 to February 16, 2021 on the UNA campus, whose student population is estimated by the Education Department at more than 7,000 students at the time of our study.

\section{Collection of food samples}

Sampling was carried out from randomly selected sellers (male and female) of ready meals and other catering foods on the UNA campus. The choice of sampling sites was made according to the most frequented points of sale and seven (7) points were listed on the campus: IREN market, AMPHI B - schooling, fixed restaurant, ex-Lacena gallery, the gallery of rooms of public works and service offices.

Only the dishes available on the day of sampling were taken for microbiological analyzes with at least two hundred (200) grams of each dish. Regarding resistance meals, accompaniments such as sauces and seasonings have been taken into account separately. Samples were taken by purchasing portions in the sales packaging (plastic bags) and transported to the laboratory using a cooler containing ice accumulators (Table I). In total, twenty-two (22) dishes divided 
respectively into thirty-four (34) food samples were taken. These samples were analyzed on the same day they were collected.

The dishes for which the analysis was necessary to differ were stored in the refrigerator (LIEBHERR) at $+3{ }^{\circ} \mathrm{C}$ or in the freezer (LIEBHERR) at $-18^{\circ} \mathrm{C}$. Each vendor was revisited in 3 different periods spaced 2 weeks apart to collect the same dishes from the different UNA sites.

\section{Microbiological analyzes}

The presence of total mesophilic aerobic flora (FAMT), coliforms (total and thermotolerant), pathogenic staphylococci including Staphylococcus aureus, faecal streptococci, sulfite-reducing anaerobes (ASR) and Clostridium perfringens and salmonella was studied.

A quantity of $25 \mathrm{~g}$ of each sample was ground, homogenized or solubilized in $225 \mathrm{~mL}$ of buffered peptone water (EPT) (Bio-Rad) in a sterile stomacher bag if necessary to obtain stock suspensions. Series of decimal dilutions were made under aseptic conditions from $1 \mathrm{ml}$ of each stock suspension in a solution of $9 \mathrm{ml}$ of tryptone-salt (Bio-Rad) and used for the enumeration and search for the microorganisms to be studied.

Mesophilic aerobic bacteria (GAM or FAMT) were counted on plate count agar (PCA) medium according to the NF ISO 4833 (2003) method. The total and thermotolerant coliforms were counted on VRBL medium (Bio-Rad) by incubation at $37^{\circ} \mathrm{C}$. for 24 hours. The enumeration of all characteristic colonies was made according to ISO 4832 (February, 2006).

The enumeration of presumed pathogenic staphylococci and of Staphylococcus aureus was carried out according to standard ISO
6888-1 \& 2: July 2003. The enumeration of $S$. aureus colonies was carried out on solid medium (Baird-Parker medium) after incubation at $37^{\circ} \mathrm{C}$ for 48 hours. The sulfitereducing anaerobes were counted in the tryptone sulfite agar medium with neomycin (TSN) according to the NF ISO 15213 (2003) method. The stock suspensions were incubated at $43^{\circ} \mathrm{C}$ for 3 to $6 \mathrm{~h}$ then $0.1 \mathrm{~mL}$ of these suspensions was injected into $10 \mathrm{~mL}$ of Rapapport Vassiliadis broth. From the Rap Report Vassiliadis broth, Hektoen agar was inoculated for the detection of Salmonella strains. The inoculated dishes are steamed at a temperature of $37^{\circ} \mathrm{C}$. for 24 hours. Identification was made by classical biochemical methods.

Results obtained were expressed in colony forming units (CFU). The values of $\mathrm{N}$ were calculated for each flora studied as a function of the samples, then compared with the normative references of the microbiological criteria and of the appreciation of the quality of the samples which foodstuffs and readymade meals must satisfy (EC Regulation $\mathrm{N}^{\circ}$ 2073 / 2005).

These criteria are presented in Table II. The interpretation of the results derives from a three-class plan and is carried out as follows: when the values obtained are lower than the criteria and up to three (3) times the criterion, the product is of satisfactory microbiological quality (QMS). The product is of acceptable microbiological quality (AMQ), when the values obtained are between three (3) and ten (10) times the criterion. Finally, the microbiological quality is unsatisfactory (QMNS), when the values obtained are greater than ten (10) times the criterion.

Multiple analysis of variance (ANOVA) was used to determine the significance of the differences obtained between the values of the bacterial parameters studied. This significance 
is determined by comparing the probability $\mathrm{P}$ associated with the statistic of the FischerSnedecor test with the theoretical threshold of $\alpha=0.05$. All the tests were carried out using Microsoft software (excel XLSTAT 2016) and SAS software (SAS, 1999).

\section{Results and Discussion}

In the samples analyzed, several microorganisms such as Mesophilic Aerobic Germs (GAM) or Total Mesophilic Aerobic Flora (FAMT), thermotolerant coliforms (C. th) in particular E. coli, faecal streptococci (Strep. F) and sulphite anaerobes -reducers (ASR) were found (Table III).

Pathogens such as Staphylococcus aureus and Clostridium perfringens have also been found. As for Salmonella, they were not found in any of the samples analyzed.

The germ loads (colony forming unit : CFU) vary according to the nature of the germ, its origin and the nature of the food collected. GAM loads vary from $9.4108 \pm 1.5108 \mathrm{CFU}$ / g to $6.3101 \pm 2.5101$ and these loads are significantly different $(\mathrm{P}>0.05)$ from food to food. Another with the exception of those on sale sites, IREN / market where Akassa sauce and cooked meat sold have the same load in mesophilic aerobic germs.

Attiéké-garba, these condiments and the banana foutou sold at school as well as the tchep condiments sold on the IREN / market site presented the highest mesophilic aerobic germ loads.

The total coliform loads of the different samples range from 0 to $7.9103 \pm 2.8103$ CFU/g. The curds sold at Lacena / Ambulant showed the highest total coliform load (7.9 $103 \pm 2.8103 \mathrm{CFU} / \mathrm{g}$ ), followed by attiékégarba condiments $(7.6103 \pm 2.2103 \mathrm{CFU} / \mathrm{g})$ and akassa (6.8 $103 \pm 1.2103 \mathrm{CFU} / \mathrm{g})$ sold at
IREN-marché. In terms of the load of thermotolerant coliforms, it varies from 0 to 4 $103 \pm 2103 \mathrm{CFU} / \mathrm{g}$. The curds of ex-Lacena and the condiments of attiéké-garba sold next to schooling showed the highest loads of thermotolerant coliforms with isolation of Escherichia coli in these two dishes.

Faecal streptococci (Strep. F) are present in high quantities in the condiments of attiékégarba, akassa of IREN, schooling and restaurant-fixes as well as in the condiments of tchep sold by the ambulant / Alima. Faecal streptococci are also found in curdled milk sold to the former Lacena.

The Staphylococcus aureus are present in condiments attiéké-garba and the akassa sold IREN-market as well as plantain foutou (banana) and condiments attiéké-garba sold to schooling.

ASR are present in abundance in Attiéké taken at Restaurant and in tchep condiments sold by Ambulant / Alima. The strains of Clostridium perfringens have been identified only in the gouagouassou sauces sold at the IRENmarché, the attiéké condiments from the restaurant-fixes and in the pains au lait from the former Lacena. No strain of salmonella was identified in the samples taken (Table III and IV). Concerning the microbiological quality of the samples taken, the samples of attiéké-garba and their condiments taken at the IREN-market and at the level of vendors next to schooling are of unsatisfactory microbiological quality. The same goes for seed sauces, tuna fish, plantain (banana) foutous sold at school, tchep condiments from the ambulant / Alima. Thus, with regard to the microbiological criteria retained, $60 \%, 33.3$ $\%, 25 \%$ and $13.3 \%$ of the samples taken respectively from the sites of the schooling, IREN-marché, the fixed-line restaurant and the street vendors are -they of unsatisfactory microbiological quality (Fig. 1). 
Table.1 Ready meals and other foods taken from the UNA campus for microbiological and hygienic analysis

\begin{tabular}{|c|c|c|}
\hline \multicolumn{2}{|c|}{ Ready meals and other pre-prepared foods } & Sample number \\
\hline 1 & Chepdjèn rice & 03 \\
\hline 2 & Minced beef & 02 \\
\hline 3 & Chicken meat & 01 \\
\hline 4 & Baked pork in sauce & 02 \\
\hline 5 & Fried fish & 01 \\
\hline 6 & Tchepdjèn condiments & $\mathbf{0 3}$ \\
\hline 7 & White rice & 01 \\
\hline 8 & Attiéké & 02 \\
\hline 9 & Attiéké condiments & 01 \\
\hline 10 & Attiéké-garba & 02 \\
\hline 11 & Attiéké-garba condiments & 02 \\
\hline 12 & Fried tuna attiéké-garba fish & 02 \\
\hline 13 & Potato leaf sauce in red oil + beef & 01 \\
\hline \multicolumn{2}{|c|}{ Prepared meals and other sampled foods (continued) } & Sample number \\
\hline 14 & Gouagouassou sauce with smoked fish & 01 \\
\hline 15 & Okra seed sauce + smoked beef skin & 01 \\
\hline 16 & Akassa sauce + smoked beef skin & 01 \\
\hline 17 & Sauteed peppers and onion slices & 01 \\
\hline 18 & Akassa & 01 \\
\hline 19 & Plantain foutou (banana) & 01 \\
\hline 20 & Curdled milk & 03 \\
\hline 21 & Milk bread & 01 \\
\hline 22 & Plantain chips (banana) & 01 \\
\hline \multicolumn{2}{|r|}{ Total } & 34 \\
\hline
\end{tabular}

Table.2 Microbiological criteria relating to ready meals (CE Regulation, 2005).

\begin{tabular}{|c|c|c|c|c|c|c|c|c|c|}
\hline FAMT & C. $\mathbf{T}$ & C. Th & E. coli & $\begin{array}{c}S . \\
\text { aureus }\end{array}$ & Strep. $f$ & ASR & C. perf & LM & Salm. \\
\hline (UFC/g) & (UFC/g) & (UFC/g) & (UFC/g) & (UFC/g) & (UFC/g) & (UFC/g) & (UFCl & (UFC/g) & (UFC/g) \\
\hline $3.10^{5}$ & 10 & 10 & 10 & $10^{2}$ & - & 30 & - & $5.10^{2}$ & Absence \\
\hline \multicolumn{10}{|c|}{$\begin{array}{l}\text { FAMT: Total Mesophilic Aerobic Flora; C. T: Total coliforms; C.Th: Thermotolerant Coliforms; E. Coli : EschericiaColi ; S } \\
\text { aureus : Staphylococcus aureus ; Strep. f: Faecal streptococci; ASR: Anaerobic Sulfito Reducers; C. perf: Clostridium } \\
\text { perfringens ; LM: Yeasts and Molds; Salm : Salmonella. }\end{array}$} \\
\hline
\end{tabular}


Table.3 Microbial load of samples taken from the different sites

\begin{tabular}{|c|c|c|c|c|c|c|c|c|c|c|c|c|c|c|c|}
\hline & \multicolumn{8}{|c|}{ IREN-MARCHE } & \multicolumn{4}{|c|}{ AMBULANT-ALIMA } & \multicolumn{3}{|c|}{ RESTAURANT } \\
\hline & $\begin{array}{c}\text { Attiéké } \\
- \\
\text { garba }\end{array}$ & $\begin{array}{l}\text { Condim } \\
\text { e nts } \\
\text { garba }\end{array}$ & Akassa & $\begin{array}{l}\text { Sauc } \\
\text { e/ } \\
\text { akass } \\
\text { a } \\
\end{array}$ & $\begin{array}{c}\text { Sauce } \\
\text { gouagou } \\
\text { a ssou }\end{array}$ & $\begin{array}{c}\text { Condimen } \\
\text { s tchep }\end{array}$ & $\begin{array}{l}\text { Viand } \\
e \text { du } \\
\text { riz } \\
\text { tchep }\end{array}$ & $\begin{array}{l}\text { Porc } \\
\text { au } \\
\text { four }\end{array}$ & $\begin{array}{c}\text { Condimen } \\
\text { ts } \\
\text { tchep }\end{array}$ & Riz tchep & $\begin{array}{c}\text { Viande cuite } \\
\text { de bouf } \\
\text { pour tchep }\end{array}$ & $\begin{array}{l}\text { Viande } \\
\text { de } \\
\text { poulet } \\
\text { pour tcheh }\end{array}$ & Attiéké & $\begin{array}{c}\text { Condi } \\
\text { m } \\
\text { ents } \\
\text { /Attiéké }\end{array}$ & $\begin{array}{c}\text { Pois } \\
s \\
\text { fr } \\
t\end{array}$ \\
\hline FAMT & $\begin{array}{l}2,710^{3}= \\
1,510^{98}\end{array}$ & $\begin{array}{r}2,810^{6}= \\
1,210^{6 \mathrm{e}}\end{array}$ & $\begin{array}{c}9,310^{4} \pm \\
3,410^{4 f}\end{array}$ & $\begin{array}{r}5,210^{2}= \\
2,210^{2 \mathrm{t}}\end{array}$ & $\begin{array}{l}2,410^{3}= \\
1,210^{3} 8\end{array}$ & $\begin{array}{l}4,310^{3}= \\
2,210^{6 \mathrm{t}}\end{array}$ & $\begin{array}{l}5,710^{2}= \\
3,810^{2 \mathrm{~h}}\end{array}$ & $\begin{array}{r}4,510^{5}= \\
1,710^{5 f}\end{array}$ & \begin{tabular}{|c|}
$1,1 \quad 10^{7} \pm 2,0$ \\
$10^{7 d}$
\end{tabular} & $\begin{array}{c}5,710^{3} \\
\pm 1,2 \quad 10^{9} \mathrm{~g}\end{array}$ & $\begin{array}{c}6,310^{\mathrm{t}} \\
\pm 2,510^{\mathrm{ti}}\end{array}$ & $\begin{array}{c}1,410^{5} \\
\pm 5,910^{5 f}\end{array}$ & $\begin{array}{l}3,310^{2} \pm \\
1,510^{2 \mathrm{~h}}\end{array}$ & $\begin{array}{c}6,410^{4}= \\
1,310^{4 f}\end{array}$ & $10^{3}$ \\
\hline C. T & $\begin{array}{c}310^{2}= \\
2,810^{2}=\end{array}$ & $\begin{array}{r}7,610^{3}= \\
2,210^{3=}\end{array}$ & $\begin{array}{l}6,810^{3}= \\
1,210^{3=}\end{array}$ & 0 & 0 & 0 & 0 & 0 & 0 & $10^{2}=10^{2}=$ & 0 & 0 & 0 & 0 & 0 \\
\hline C. Th & $10^{2}=10^{\circ}$ & $\begin{array}{c}2,510^{1}= \\
1,110^{2 \mathrm{e}}\end{array}$ & $\begin{array}{cc}6,5 & 10^{2} \pm 1,3 \\
1 n^{2 b}\end{array}$ & 0 & 0 & 0 & 0 & 0 & 0 & 0 & 0 & 0 & 0 & 0 & 0 \\
\hline Strep. $\mathbf{f}$ & $9,510^{16}$ & $\begin{array}{c}2,510^{3}= \\
1,410^{\mathrm{s}}\end{array}$ & $\begin{array}{l}410^{3}= \\
210^{32}\end{array}$ & 0 & 0 & 0 & 0 & 0 & $\begin{array}{c}2,310^{3}= \\
110^{\mathrm{x}}\end{array}$ & 0 & 0 & 0 & 0 & $4,110^{72}$ & 0 \\
\hline S. aureus & 0 & $10^{t=}$ & $10^{t=}$ & 0 & 0 & 0 & 0 & 0 & 0 & 0 & 0 & $\mathrm{O}$ & 0 & 0 & 0 \\
\hline ASR & 0 & 0 & $10^{2} \pm 10^{\circ d}$ & $\begin{array}{l}10^{2} \pm \\
10^{\text {od }}\end{array}$ & $\begin{array}{lll}5,5 & 10^{2} \pm \\
0,3 & 10^{2 \mathrm{e}}\end{array}$ & 0 & 0 & 0 & $\begin{array}{c}2,110^{3}=1 \\
10^{3=}\end{array}$ & 0 & 0 & 0 & $\begin{array}{c}210^{3}= \\
10^{2 b}\end{array}$ & 0 & 0 \\
\hline C. perf & 0 & 0 & 0 & 0 & $10^{2}=10^{2}$ & 0 & 0 & 0 & 0 & 0 & 0 & 0 & 0 & $\begin{array}{c}4,010^{1}= \\
210^{-1}\end{array}$ & 0 \\
\hline Salm & ABS & ABS & ABS & $\mathrm{ABS}$ & $\mathrm{ABS}$ & ABS & $A B S$ & $\mathrm{ABS}$ & $\mathrm{ABS}$ & $\mathrm{ABS}$ & $\mathrm{ABS}$ & $\mathrm{ABS}$ & $\mathrm{ABS}$ & $\mathrm{ABS}$ & A \\
\hline
\end{tabular}

FAMT : Total Mesophilic Aerobic Flora ; C. T : Total coliforms; C. Th : Thermotolerant Coliforms; E. Coli : Escherichia Coli ; S aureus : Staphylococcus aureus ; Strep. F : Faecal streptococci ; ASR : Anaerobic Sulfito Reducers; C. perf : Clostridium perfringens ; Salm : Salmonella 
The microbial loads of the germs found in the samples of attiéké-garba and these condiments (GAM, thermotolerant coliforms, Clostridium perfringens, faecal streptococci) are higher than those tolerated for cooked dishes. The presence of all these germs could be explained by the conditions of the practice of the activity of production and marketing of attiéké-garba. Indeed, all the germs found in the samples could come from the sales environment (open air sales, etc.), from the vendors themselves (dirty hands and clothes) or even from elements involved in the preparation of the attiéké. garba. Certain studies have already indicated the presence of mesophilic aerobic bacteria, total coliforms and thermotolerant coliforms in attiéké (Koffi et al., 2004; Kouamé et al., 2012). The high load of GAM in the condiments of attiéké-garba can be explained by the fact that the fresh vegetables, namely the tomato, the pepper and the onion can also constitute contributions of sprouts if they are not fresh and / or, not properly washed. Vegetables are, in fact, commonly involved in cases of food poisoning (Belomaria et al., 2007). The fish used in the accompaniment can however be little incriminated because it is fried and generally served very hot.

Regarding tchep condiments, sauces and plantain foutou (banana), their contamination could come from the sales environment, from the sellers themselves (dirty hands and clothes). In this study, apart from the samples taken at school where $60 \%$ of the samples did not meet the microbiological criteria used, nearly $65 \%$ of the samples taken at the other sites complied with the microbiological standards in force.

Sylla and Seydi (2003) obtained $84 \%$ satisfactory results in a study of the microbiological quality of the meals served at the center of university works in Dakar. However, the large part of the nonconforming samples being attributable to attiéké-garba and its condiments but also samples of curdled milk contaminated by strains of Escherichia coli and Staphylococcus aureus; this constitutes a real danger to the health of consumers, in particular students. Ahota et al., (2010) as well as Sylla and Seydi (2003) also found similar contaminations in foods sold on campuses, in particular the campus of the University of Abomey Calavi in Benin. Likewise in Abidjan, the work of Yoro et al., (2003), which focused on the microbiological analyzes of foods from 1990 to 1995 , mentioned that $1.2 \%$ of the meals analyzed were contaminated by Staphylococcus aureus. Indeed, attiéké-garba is a dish that is very popular and consumed by students because of its low cost to purchase. The sanitary and hygienic aspect of this dish deserves to be watched.

The objective of this work was to study the microbiological quality of ready meals and other foods sold in makeshift catering areas installed on the campus of NANGUI ABROGOUA University. The microbial loads of the germs found in the food samples analyzed indicate that the majority of the samples are of satisfactory quality compared to the microbiological criteria. However, the microbial loads of the germs found in attiékégarba, its condiments and certain cooked dishes are higher than the norm with the isolation of strains of Escherichia coli and Staphylococcus aureus. These results suggest that the consumption of these foods could pose a risk to the health of consumers. It is therefore necessary to improve the hygienic quality of the meals served, in particular attiéké-garba, to ensure better consumer safety. Therefore, we advocate raising awareness of good hygienic and manufacturing practices to stakeholders in the catering busness (industry) on the UNA campus. 


\section{Conflict of Interest}

The authors declare that there is no conflict of interest for this article.

\section{Acknowledgement}

Authors thank to the management of the Central Analysis Laboratory (LCA) of the NANGUI ABROGOUA University who made this work possible in its structure.

\section{References}

Ahoyo, T A, Ahissou, H., Kounon, F., Aminou, T., Dramane, K., 2010. Study of the bacteriological quality of foods sold on the campus of the University of Abomey Calavi in Benin Int. J. Biol. Chem. Sci. 4 (4): 1083-1092.

Barro, N. Lassina, S. Marc, C. T, Sheik, A T, Traore, A. S., 2005. The main agents of the identified risk in street food and those of canteens and their prevalence in the middle hospital, Master processes to improve the food quality and safety, use of GMO, risk analysis in food Ouagadougou, 8-11.

Belomaria, M., Ahami O. A T., Aboussaleh, Y., Elbouhali, B., Cherrah, Y., Soulaymani, A. 2007. Environmental origin of collective food poisoning in Morocco: Case of the Ghrab chrarda BniHssen region. Antropo., 14: 83-88.

Chapman, B., Eversley, T., Fillion, K., MacLaurin, T., Powell, D. 2010. Assessment of Food Safety Practices of Food Service Food Handlers: Testing a Communication Intervention. Journal of Food Protection, 73 (6): 1101-1107.

Chauliac, M., Bricas, N., Ategbo, E., Amoussa, W., Zohoun, I. 1998. Food habits outside the home by school children in Cotonou (Benin). Health, 8: 101-108.

Drabo, K M, Pare, T., Savadogo, L. G. B., Tarnagda, Z., Zeba, A. N., Zongo I., Rouamba, J., Toe A., Ouédraogo, D., Ouédraogo, J. B. 2009. Characteristics of street food in the city of Bobo- Dioulasso,
Burkina Faso. Bull Soc Pathol Exot, 102 (1): 36-40.

FAO. 2007. Food Agricultural Organization of the United Nation - FAO Good Hygienic Practice in the Preparation and Sale of Street Foods in Africa. Rome, Italy, 188p.

Fayomi, B., Josse, R., Adaye, A., Laloe, V., Djogbe, H., Zohoun, R., 1992. Foodborne illness in rural Benin. Black African Medicine, 39 (5): 364-366.

Koffi, L. B., Djedji C. E., Kamenan, A. 2004. Irreducible rate of hydrocyanic acid and microbiological quality of attiéké produced in the Abidjan region. Agron. Afr., 16 (3): 11-19

Kouame, A. K., Djeni, T. N., N'guessan, F. N., Dje, M. K. 2012. Post processing microflora of commercial attieke (afermented cassav aproduct) produced in the south of Côte d'Ivoire. Lett. Appl. Microbiol., 56 (1): 44-50.

Neffati, L., Ridha, H., Kolsteren, P., Hilderbrand, K. 2004. Street food for school children in a region of northern Tunisia. Cah. Health, 14 (1): 43-48.

Ohiokpehai, O. 2003. Nutritional aspects of street foods in Botswana. Pakistan J. Nutr., 2 (2): 76-81.

WHO (World Health Organization), 2009. Food safety; Bulletin published by the Food Safety and Zoonoses Department FOS No 35 - November 12, 2009.

Regulation (EC), 2005. Regulation (EC) $\mathrm{N}^{\circ}$ 2073/2005 of the Commission of the European Communities, of November 15, 2005, concerning the microbiological criteria applicable to food stuffs. Official Journal of the European Union. 18p.

Sylla, K. S. B. and Seydi, M. G. 2003. Study of the hygienic quality of fish used in university catering in Dakar (Senegal). RASPA, 1 (1): 17- 23

Yoro, N., Koua, A, N'gbakou, A. and Dosso, M. 2003. Review of microbiological analyzes of food in Abidjan from 1990 to 1995. Microbiology, food hygiene, 15 (44): 39 31. 


\section{How to cite this article:}

YAO Kouadio, DAN Chépo Ghislaine, NANGA Yessé Zinzendorf, KOMADE Thierry, LOUKOU Yao Guillaume and KOUAME Lucien Patrice. 2021. Microbiological Quality of Food and Ready Meals Sold in Fast Food Restaurants on the Campus of Nangui Abrogoua University in Abidjan (Ivory coast). Int.J.Curr.Microbiol.App.Sci. 10(11): 226-234.

doi: https://doi.org/10.20546/ijcmas.2021.1011.026 